\title{
THE MAASTRICHT TREATY ON EUROPEAN UNION
}

\author{
Prof. Dr. Dominik LASOK*
}

\section{Introduction}

In a technical sense the Maastricht Treaty is an amendment of the Treaty of Rome founding the European Economic Community but, in substance, it expands the area of Community activity and advances further West European economic and political integration. However, whilst adding new dimensions to the existing design it also, for the time being, sets limits to Community activity by providing that "any action of the Community shall not go beyond what is necessary to achieve the objectives of the .Treaty" and that the Community will act "only if and in so far as the objectives of the proposed action cannot be sufficiently achieved by the Member States". This double brake reflects the so-called "subsidiarity principle" which confirms that the relationship between the Member States and the Community is based on a delegation of sovereignty, the powers vested in the Community being limited in scope and their exercise confined to what is necessary to achieve the common objectives which exceed the capacity of any single Member State. The principle safeguards the residual powers of the Member States and guards against the adventurism of the Community institutions and the ambitions of their bureaucracy.

Since the Treaty aims to achieve two broad objectives, a political union and an economic and monetary union, we shall summarize its provisions under these two headings:

\section{A. TOWARDS A POLITICAL UNION}

\section{The Ever Closer Union and Institutional Adjustments}

Having dropped the "federal goal" the Treaty, like the Treaty of Rome, aims at an "ever closer Union among the peoples of Europe" which it plans to achieve whilst

\footnotetext{
- Professor of European Law, Marmara University EC Institute, (Len Dr., LLM, PhD, Dr. Juris, LLD, Dhc, of the Middle Temple, One of Her Majesty's Counsel, Emeritus Professor of European Law and former Director of the Centre for European Legal Studies at the University of Exeter).
} 
building on the EEC Treaty it amends and expands. The institutional adjustments reflect the provisions governing the economic and monetary union, the administrative and judicial functions as well as the decision-making process entailing an enhanced participation of the European Parliament (E P).

The $E P$ is given power to investigate alleged contraventions or maladministration in the implementation of Community law except where such complaints are subject to judicial proceedings ${ }^{3}$. It is not clear what it should do with the result of its investigations.

There will be a right to petition the E P vested in the citizens of the Union and any natural or legal person residing or having its registered office in a Member State in matters within the competence of the Community and which affect the complainant directly. To that end the E P shall appoint an Ombudsman ${ }^{5}$ and define his duties having received an opinion from the Commission and the approval of the Council. However the Ombudsman's duties will not include any control of the Judiciary.

The size of the Commission will be examined later on but the size of the $E P$, taking into account the re-unification of Germany, has been increased to 567 members by the Edinburgh Council in December 1992 in time for the 1994 elections. Thus Germany shall send 99 members; France, Italy and the United Kingdom 87 members each; Spain 64, The Netherlands 31; Belgium, Greece and Portugal 25 each; Denmark 16; Ireland 15 and Luxembourg 6 members. The E P will also draw up proposals for election by direct universal ${ }^{6}$ suffrage in accordance with a uniform procedure in all Member States. Upon these proposals the Council acting unanimously shall, after obtaining the assent of the $E \mathrm{P}$, lay down provisions for future elections which it shall recommend to Member States for adoption according to their respective constitutions.

The Commission's term of office will be extented to five years ${ }^{7}$ to coincide with the mandate of the E P. The President of the Commission will be nominated by the governments of the Member States ${ }^{8}$ after consulting the $E P$. In consultation with the nominee the governments will nominate the other members of the Commission and the whole body shall be subject to a vote of approval by the E P. After such approval the President and the members of the Commission shall be appointed by common accord of the Member States. Deputy Commissioners will be nominated by the Commission and appointed by the Council acting by a qualified majority. 
For the contingency of a Member State not complying with the judgment of the Court of Justice an improved procedure ${ }^{9}$ has been devised. Accordingly the Commission will issue a reasoned opinion specifying the failure of the State concerned and requiring it to take the prescribed measures. If the State does not comply within the requisite time-limit the Commission may not only bring the case before the ECJ but also move that the Court imposes a fine or penalty upon the defaulting State. This should increase the efficiency of the enforcement procedure.

The jurisdiction of the ECJ has also been updated ${ }^{10}$. The Court will review the legality of acts of the E P and the Council, of the Council, of the Commission and of the European Central Bank (ECB); and acts of the E P made within its sole competence if they are intended to produce legal effects upon third parties. Under Article 173 (1) of the EEC Treaty only the Member States, the Commission and the Council were competent to challenge Community acts but now the E P and the European Central Bank (ECB) will also be able to do so, albeit, only "for the purpose of protecting their prerogatives".

- Actions against failure to act have also been extended". Now the EP and the ECB figure among the institutions which may be sued for inactions like the other institutions and the potential challengers will also include the ECB. Similarly the scope of preliminary rulings under article 177 has been extended to cover the validity and interpretation of the acts of the ECB.

The ECJ's jurisdiction under EEC Article 180 in respect of the European Investment Bank (EIB) and the Member States' obligations under the statute of the EIB has been extended to cover the European System of Central Banks (ESCB) and the obligations of the national central banks under the system.

In order to accommodate the enhanced position of the E P in the decisionmaking process the Maastricht Treaty has added a "co-decision procedure" to the existing consultation, co-operation, and assent procedures in which the E P is involved. Although the $E P$ has no power to initiate Community legislation it may, acting by a majority of its members, request the Commission to submit any appropriate proposal on matters on which it considers that a Community act is required for the purpose of implementing the Maastricht Treaty.

The co-decision procedure has added a new complexity to the Community process. It should work as follows:

(a) Commission makes a proposal to the E P and the Council; 
(b) E P gives its opinion and the Council, acting by a qualified majority, adopts a common position and informs the $E P$ accordingly;

(c) Thereupon:

(aa) the E P can, within three months, either approve the common position or take no decision in which case the Council will adopt the measure;

(bb) the E P can, by an absolute majority, reject the common position and inform the Council which will convene a meeting of the Conciliation Committee representing the Council and the $E P$ in equal numbers;

(cc) at this stage the E P may again reject the proposal by absolute majority in which case the proposal cannot be adopted or, alternatively, propose amendments;

(dd) if the E P proposes amendments the Council may, within three months, either approve the amended text by a qualified majority (but not the amendment opposed by the Commision for which unanimity is required) or refuse to approve in which case the Conciliation Committee will be convened again;

(d) the Conciliation Committee has to produce a joint text within six weeks, which will be adopted if approved by a majority of votes cast in the $E P$ and a qualified majority of the Council; but effectively killed if either institution fails to approve.

(e) if the Conciliation Committee fails to agree the Council can either abandon the proposal or, within six weeks, confirm its original position ( (b) above ); in the latter case the E P has another six weeks within which it can reject the text by an absolute majority of its members.

In effect the $E P$ has acquired a power of veto over the legislation governed by the co-decision procedure. If exercised it will hardly enhance the process of legal integration already overburdened by procedural complexities.

\section{The Citizenship of the Union}

Furthering the notion of a "People's Europe" the Treaty purports to establish "citizenship ${ }^{13}$ of the $E C^{\prime}$ to which every person holding the nationality of a Member State is entitled. The citizenship of the Union entails the right to move freely and reside within the territory of the Member States, the right to vote and to stand as candidate at municipal elections as well as the right to vote and stand as a candidate in elections to the European Parliament in the country where the citizen resides ${ }^{14}$. The stand as candidate and vote in elections to European Parliament has been approved 
by Council Directive 93/109 in time for the 1994 elections. However the other principles are subject to implementation by the Council acting unanimously on a proposal from the Commission after obtaining the assent of the E P. There is as yet no right (active or passive) to participate in general elections.

Whilst in a third country every citizen of the $\mathrm{E} C$ shall be entitled to diplomatic and consular protection ${ }^{15}$ of any Member State on the same conditions as the nationals of that State. To implement this objective the Member States must, before 31 December 1993, establish between themselves the necessary rules and to secure this protection by means of appropriate international negotiations.

\section{Transport Policy, State Aids and Tax}

Most of the Community policies enshrined in the EEC Treaty remain substantially unchanged. However the Transport ${ }^{16}$ Policy has to be strengthened by measures improving transport safety. State aids ${ }^{17}$ may be permitted also if designed to promote culture and heritage conservation provided they will not effect trading conditions and competition.

Taxation ${ }^{18}$ policy is due to be extended by the legislation harmonizing turnover taxes, excise duties and other forms of indirect taxation as far as it is necessary for the establishment and functioning of the internal market.

\section{Immigration, Justice and Home Affairs}

There will be a common policy on immigration ${ }^{18}$ as the Council will determine uniform visa requirements for citizens of third countries entering the $\mathrm{EC}$.

However this policy will be merely linked with intergovernmental action expressed in co-operation ${ }^{20}$ in the spheres of justice and home affairs between the Member States thus accentuating the residual competence of the latter. In particular the Member States will devise a common approach to the granting of asylum ${ }^{21}$ and the conditions of entry and movement of third country nationals on their territories. These conditions will comprise rules governing family reunion, access to employment, unauthorised immigration and police co-operation for the purpose of preventing and combatting terrorism, unlawful drug trafficing and other serious forms of 
international crime and fraud. In this field the Member Staes are bound to respect the European Convention on Human Rights and Fundamental Freedom as well as the Convention on the Status of Refugees and continue extending their protection ${ }^{22}$ to persons persecuted on political grounds without prejudice to their responsibility for maintaining law and order and internal security.

\section{Economic and Monetary Policy}

Elaborate provisions expand the scope of the political union into economic and monetary fields which, in view of their importance merit a more detailed outline and will be discussed below.

\section{Social Provisions}

Whilst the social provisions of the EEC Treaty remain unchanged the Treaty extends the policy on education, vocational training and youth ${ }^{23}$. In this area the E C shall endeavour to develop the European dimension in education particularly through the teaching of languages, mobility of students and teachers, co-operation between educational establishments, exchange of information and experience in the field and the development of distance education.

The vocational training policy shall support and supplement the action of the Member States whilst the later carry on their responsibility for the content and organization of such training. Here a division of competences is emphasized since the Community action will focus attention on the adaptation of training and re-training to changes in industry, exchange of instructors and trainees, exchange of information on issues common to the training systems of the Member States and co-operation between training establishments and firms. The Council shall adopt measures to achieve these objectives without, however, attempting any harmonization of the laws and regulations of the Member States.

Both in the sphere of education and vocational training the Community and the Member States shall aim to establish co-operation with third countries and the relevant international organizations ${ }^{24}$.

In view of the British opposition to the inclusion of the Social Charter ${ }^{25}$ of 1989 championed by the Commission, eleven Member States concluded a separate Agreement for the implementation between themselves of the Charter which is em- 
bodied in a protocol ${ }^{26}$ attached to the Treaty. Any implementing legislation will be adopted by the Council on a proposal from the Commission either by a unanimous vote of the eleven or by a qualified majority in derogation from article 148 (2) of the EEC Treaty adapted for the purpose. Accordingly the majority will consist of 44 votes out of 66 instead of 54 out of 76 as laid down in the EEC Treaty. However the Council will endeavour to get the UK involved and thus secure the participation of all the Member States. The U K is free to join. Where it does not wish to be involved the UK will not take part in the deliberations and consequently will not be bound by the decisions of the eleven. The opting out does not affect the proposals currently under consideration, i.e. working time, social security for migrant workers and the protection of pregnant women.

The eleven have agreed to apply the unanimity principle to such issues as the social security and protection of workers; redundancy; representation of employers and workers and collective bargaining; employment of nationals of third countries and financial contributions to job creation.

Qualified majority will apply to measures concerned with working conditions; health and safety; information and consultation of workers; equality of the sexes as regards employment opportunities and treatment at work; and the integration into the workforce of persons excluded from the labour market in view of their disabilities.

Whilst the level of wages; the right of association; the right to strike and to lockout are not included in this programme, the Agreement reiterates the principle of equal pay for men and women.

\section{Consequential Policies}

Apart from expanding certain existing policies the Treaty reflects some new initiatives, i.e.:

\section{(a) Economic and Social Cohesion ${ }^{27}$}

In order to reduce the prosperity gap and thus reinforce the regional policy new measures will be taken with the object of financially assisting the less developed areas. To that end a Committee of the Regions ${ }^{28}$ representing regional and local authorities is to be set up. It will consist of 189 members: twenty-four from each of the larger four Member States, down the scale to six from Luxembourg. It will reflect the structure of the Economic and Social Committee and act in a consultative capacity 
for the Council and the Commission. It may submit to these bodies its own views on matters it considers relevant to the regions.

The policy is to be financed by a special Cohesion Fund ${ }^{20}$ in addition to the existing structural funds and the European Investment Bank which will support national programmes directed especially to the establishment of trans-European networks in transport, telecommunications and energy infrastructures.

(b) Research and Technological Development ${ }^{30}$

In order to strengthen the scientific and technological bases of Community industry and make the industry more competitive at international level the Council will adopt a multiannual framework programme to promote research and disseminate its results. The function of the Community in this area is to encourage co-operation of the relevant sectors combining academic and practical work and to lay down rules for such co-operation complementing the activities carried out in the Member States.

(c) Environment ${ }^{31}$

The Treaty restates the objectives of the E C policy for the environment aiming at a "high level of protection taking into account the diversity of situations in the various regions of the Community". Thus the existing programme ought to be implemented with renewed vigour, integrated with other Community policies and related to third countries and international organizations. Moreover, the Council, acting unanimously shall adopt measures of a fiscal nature, concerning town and country planning, land use and choice of energy sources. However, without prejudice to the principle that the pollutor must pay, Member States may be allowed a temporary derogation from their obligations and obtain financial support from the Cohesion Fund if the implementation of any of the above mentioned measures involves excessive costs.

(d) Industry ${ }^{32}$

Provided that they will not distort competition the Council, acting unanimously, will enact measures supporting the Member States in their endeavour to adjust industry to structural changes, encourage initiatives of small and medium-sized undertakings, create a favourable environment for co-operation between undertakings and 
foster better exploitation of the industrial potential of policies of innovation, research and technological development.

\section{(e) Public Health ${ }^{33}$}

The Council, acting by qualified majority, will develop concerted action towards the prevention of diseases, (in particular the major health hazards) including drug dependence by promoting research, health information and education. The Member States will, in turn, co-ordinate their policies and programmes in liaison with the Commission.

\section{(f) Culture $^{34}$}

Working closely with third countries, international organizations and, in particular, with the Council of Europe the Community shall contribute to the development of the European culture whilst respecting the regional and national cultural diversities of the Member States. Any incentives in this field, excluding the harmonization of the laws of the Member States, have to be taken by the Council unanimously after consulting the Committee of the Regions.

\section{(g) Development Co-operation ${ }^{35}$}

Without prejudice to the co-operation with the ACP (i.e. the Lomé Convention) countries the Community policy in this field shall be complementary to the policies of the Member States. The aims of the Community policy shall be to foster social and economic development of developing countries, their integration into the world econormy, fight against poverty and contribution towards the development and consolidation of democracy, the rule of law and respect of human rights and fundamental freedoms. Acting within their respective competences the Community and the Member States shall co-operate with third countries and international organizations.

\section{(h) Consumer Protection ${ }^{36}$}

Aiming for a "high level of consumer protection" the Community shall take measures in the context of the completion of the internal market or specific action which supports and complements the policy of the Member States to protect the interests of consumers. Such action shall not prevent any Member State from main- 
taining more stringent protective measures provided they are compatible with the Treaty.

- (i) Further Policies ${ }^{37}$

The Treaty envisages further, as yet undefined, policies for energy, civil protection and tourism but these will be considered in the light of the Commission report in 1996. In the meantime the Community action in these fields shall be based on the existing Treaty provisions.

\section{Common Foreign and Security Policy}

Perhaps the most promising achievement of the Treaty lies in the development of Common Foreign and Security Policy as one of the pillars of the emerging Union. The objectives ${ }^{39}$ of such policy shall be:

(a) to safeguard the common values, fundamental interests and independence of the Union;

(b) to strengthen the security of the Union and of the Member States;

(c) to preserve peace and strengthen international security in accordance with the principles of the U N Charter as well as the principles of the Helsinki Act and the objectives of the Paris Charter;

(d) to develop and consolidate democracy and the rule of law and respect for human rights and fundamental freedoms.

In order to achieve these objectives the Union shall establish systematic cooperation ${ }^{40}$ between Member States and implement joint actions in the areas in which the Member States have essential interests in common. Thus the functions are divided: the Union shall provide leadership and the Member States their co-operation. Since, however, national policies are not excluded the necessary co-ordination shall occur within the Council of Ministers. Where necessary the Council shall define a "common position" to which the national policies must be aligned. A common position co-ordinates also the conduct of the Member States in international organizations and at international conferences where they ought to protect not only their own interests but also the interests of their fellow Member States which are not present on such occasions. 
General guidelines ${ }^{41}$ for any joint action are to be laid down by the European Council but the details are to be worked out by the Council of Ministers. The decision to take a joint action must be reached unanimously but specific arrangements arising therefrom are subject to a qualified majority in accordance with article 148 (2) of the Treaty. It seems, however, that where a qualified majority exists in favour of a joint action the Council may avoid seeking unanimity by proceeding according to a qualified majority. This implies the absence of veto or call for unanimity. A joint action decision is binding upon the Member States but the position will be reviewed if there is a substantial change of the circumstances.

A joint action decision may allow for separate national actions but in such a case there must be consultations within the Council before any steps at the national level are taken. In cases of "imperative need" (undefined in the Treaty) unilateral measures may be taken as a matter of urgency, but only in accordance with the objectives of the joint action and having notified the Council. If a State experiences "major difficulties" in implementing a joint action the Council must be advised and seek a solution to the problem.

As can be seen the Union (and within it the EC) has not reached as yet the stage of having its own autonomous external policy. The Union (and within it the EC), as a legal person, ${ }^{43}$ has the capacity to enter into external relations within the scope of the Treaties but the Member States have not relinquished all their original powers in this field in favour of the Union (and within it the EC) and consequently, a bicephalous conduct of external relations continues.

Following the disintegration of the U S S R and of the Warsaw Pact the security position in Europe has changed substantially. NATO, with its American protective umbrella, has to be adapted to a new role. This, coupled with the developing political integration and the growing awareness of Europe's responsibility for its own safety, has led to the linkage of a common foreign and security policy in the Maastricht Trea$\mathrm{ty}^{\mathrm{A}}$. However the security provisions reflect only a reaction to the present situation. Thus "the Union shall request the Western European Union (WEU), which is an integral part of the development of the European Union, to elaborate and implement decisions and actions which have defence implications". The Council of Ministers is charged with the task of adopting "the necessary political arrangements" with the W E U but the issues invoived are not subject to the procedure for reaching joint actions within the Union. However, according to an agreement reached with the W E U (which includes nine of the $\mathrm{E} C$ countries), the Union shall respect the NATO obligations of certain Member States (e. g. France) and shall not prejudice their national 
defence policy. It shall not hinder any bilateral arrangements in the framework of WEU and NATO (e.g. Franco-German military co-operation).

In matters covered by the common foreign and security policy the Union shall be represented by its Presidency assisted, if need be, by the previous and next State to hold the Presidency. However the general principles and guidelines will be defined by the European Council whilst the Council of Ministers will, by unanimous decisions, carry out the implementing tasks. These decisions may provide for details to be settled by qualified majority.

The Commission shall be "fully associated"4t6 but the E P only "regularly informed" by the Presidency of the decisions taken in the field of foreign and security policy. However the Presidency ought to consult ${ }^{47}$ the E P on the main aspects of the Union's foreign and security policy whilst the E P may submit questions and recommendations to the Council. It also ought to hold an annual debate on the subject.

\section{Financial Provisions}

Clearly the expansion of policies will necessitate additional expenditure. Indeed the President of the Commission estimated ${ }^{48}$ that the $E$ C budget needs to grow by $30 \%$ over the next five years. The revenue necessary to finance the common foreign and security policy and the co-operation in the field of justice and home affairs will be provided from the E C's own resources ${ }^{49}$. The same applies to policies already financed by the $\mathrm{E} C$. Therefore, although the Commission, when proposing new measures, must make sure that these can be financed within the limits of the own resources, the Council must look for additional funds and, to that end, shall make recommendations to the Member States.

In order to improve the budgetary discipline additional powers are granted to the Court of Auditors ${ }^{50}$ which shall assist the E P and the Council in exercising their powers of control over the implementation of the budget. The E P will be able to exact from the Commission evidence with regard to expenditure and financial control and the Commission will be obliged to act on the observations of the $E P$.

Member States are bound to take measures to combat frauds ${ }^{51}$ affecting the financial interests of the EC and to that end they will, with the help of the Commission, arrange for co-operation between their respective authorities. 


\section{Comments}

The Maastricht Treaty continues and expands the process of economic and political integration of the $\mathrm{E} C$ but, at the same time, endeavours to draw, according to the principle of subsidiarity, a line between the residual State competence and the ever-expanding competence of the $\mathrm{EC}$, now to be called the European Union.

The institutional reform reflects a slow but gradual ascendancy of the $E P$ resulting in yet another cumbersome procedure to deal with legislation implementing the Maastricht decisions.

There is a great deal of repetition regarding the existing and emerging economic policies as the Treaty endeavours to tidy up the updated text. However the British abstention from the Social Charter sounds a jarring note in the otherwise harmonious crescendo of the European integration. Since the Community is an economic - social venture the gap will have to be filled in due course when the ear of a British government will be more closely attuned to a suitably modified pitch.

The Treaty continues the dichotomy between external economic relations which are within the E C competence and foreign policy stricto sensu to which the mechanism of the founding Treaties does not apply. Thus the new provisions linking foreign policy with security and the provisions on justice and home affairs fall short of an instrument of integration. However there is progress. In the field of foreign policy they move from co-operation between Member States to joint actions defining the objectives, taking and implementing decisions. In the field of security they move from considering closer co-operation to the idea of eventually framing a common defence policy. In the field of justice they initiate co-operation. However in all three areas the Member States retain their residual power albeit in the context of the emerging Union and subject to the principle of solidarity and subsidiarity.

\section{B. TOWARDS AN ECONOMIC AND MONETARY UNION}

\section{General Principles}

In order to achieve the objectives of the Union the Member States and the Community shall adopt an economic ${ }^{52}$ policy based on the close co-ordination of national economic policies, the internal market, and common objectives defined in accordance with an open market economy and free competition. Concurrently with these principles there shall be "irrevocable fixing of exchange rates leading to the introduction of a single monetary policy and exchange rate policy ${ }^{53 m}$ in support of the 
general economic policies in the Community. Both the Community and the Member States shall apply ${ }^{54}$ "stable prices, sound public finances and monetary conditions and a sustainable balance of payment" as their guiding principles.

\section{Movement of Capital}

As from 1 January 1994 articles 67 to 73 of the EEC Treaty shall be replaced by new provisions entailing total liberalisation ${ }^{55}$ of capital movements between the Member States and between the Community and third countries subject, however, to a possible restriction regarding third countries by a unanimous decision of the Council of Ministers ${ }^{56}$. Nevertheless the Member States shall be at liberty to derogate tax matters on the ground of the taxpayers' residence or the place where their capital is invested. They are also to be free to apply the national sanctions to infringements of national laws.

In exceptional circumstances causing serious difficulties for the operation of the economic and monetary union, the Council may take temporary safeguard ${ }^{57}$ measures restricting the movement of capital to or from third countries. Such decisions must be taken by a qualified majority on a proposal from the Commission and after consulting the European Central Bank (ECB). Furthermore, on the basis of amended article 228 which regulates the treaty-making power of the Community, the Council may take urgent measures with regard to third countries on the movement of capital and payments. As long as the Council has not acted, a Member State may take on its own initiative measures for the protection of its essential interests in matters of security connected with the production of or trade in military material but must inform the Commission and the fellow Member States. The Council, acting by a qualified majority on a proposal from the Commission, may amend or abolish the measures in question.

\section{Economic Policy}

New provisions complement and extend the EEC framework of economic policy. The Member States must regard their own economic policies as a matter of common concern and co-ordinate these within the $\mathrm{Council}^{58}$ and, in this context, the Community institutions are granted new powers. Thus the Council, acting by a qualified majority on a recommendation from the Commission, shall draft proposals for guide- 
lines of the economic policies of the Member States and the Communities and submit these to the European Council. On the basis of the European Council's conclusions the Council shall, by a qualified majority, direct a recommendation to the Member States informing the European Parliament accordingly $y^{50}$.

The Member States ought to inform the Commission of the important measures taken by them ${ }^{\infty}$. On the basis of that information the application of the guidelines shall be monitored. Where national economic policies are found to be inconsistent with the guidelines or putting the system at risk the Council, by a qualified majority, may direct appropriate recommendations to the country concerned ${ }^{61}$. The Council may decide to make these recommendations public and, on a proposal from the Commission in co-operation with the European Parliament elaborate detailed rules for the multi-lateral surveillance procedure ${ }^{62}$.

A Member State facing severe economic difficulties may, on a proposal from the Commission, receive financial assistance which the Council will grant by a unanimous decision ${ }^{6}$. If such difficulties arise from a natural disaster the decision to grant assistance shall be taken by a qualified majority ${ }^{64}$.

Overdraft facilities with the European Central Bank (ECB) or with the national central banks to Community institutions, Member States' central governments or regional organizations or to public authorities shall be prohibited, but the details of the prohibition shall be defined by the Council before 1 January $1994^{\text {as }}$.

Member States must avoid excessive budget deficits. In this context the Commission shall monitor government debt and examine the budgetary discipline. If there is a risk of excessive deficit the Commission shall inform the Council which can make recommendations to the State concerned with a view to bringing the situation under control $^{67}$. Where the State persists in failing to put these into practice the Council may give notice that within a specified time limit the deficit reduction is achieved ${ }^{68}$. Whilst the enforcement actions under articles 169 and 170 of the EEC Treaty are expressly excluded $^{69}$ in such situations it is provided that the Council may resort to certain prophylactic measures ${ }^{70}$. Thus it may require further information, invite the EIB to re-

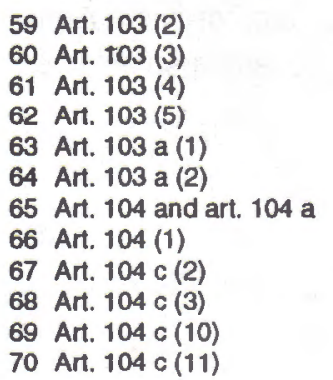


consider its lending policy towards the Member State concerned and require the Member State to make a non-interest-bearing deposit with the Community until the excessive deficit has been corrected. Ultimately it may impose fines and inform the European Parliament of its decisions which have to be taken on a proposal from the Commission by a majority of two thirds of the weighted votes excluding the votes of the State concerned.

\section{Monetary Policy}

The primary objective of the European System of Central Banks (ESCB) consisting of the European Central Bank (ECB) and the national central banks is to maintain price stability ${ }^{71}$. To that end the ECSB shall define and implement the monetary policy of the Community; ${ }^{72}$ conduct foreign exchange operations; hold and manage the official foreign reserves of the Member States; and promote the smooth operation of payments systems. It shall also contribute to the supervision of credit institutions by the competent authorities and to the stability of the financial system ${ }^{73}$.

The ECB shall have the exclusive right to authorize the issue of ECU banknotes in the Community both by the ECB and the national central banks ${ }^{75}$. Such banknotes alone shall have the status of legal tender in the Community. However Member States will be able to issue coins ${ }^{75}$ subject to ECB approval. The Council shall enact measures to harmonize denominations and technical specifications of coins ${ }^{76}$. Thus national currencies shall be replaced by a common Community currency.

The Council, on a recommendation from the ECB or the Commission shall, after consulting the European Parliament, determine by unanimity, an exchange rate system for the ECU vis-a-vis non-Community currencies ${ }^{\pi}$. However, acting by a qualified majority on a recommendation from the ECB or the Commission, the Council may adopt, adjust or abandon the central rates of the ECU within the exchange rate system. The European Parliament ought to be informed accordingly.

In derogation from the exercise of the treaty-making power regulated by article 228 of the EEC Treaty, international agreements concerning monetary or foreign exchange regime between the Community and non-Community states or international organizations, shall be negotiated and concluded according to arrangements laid 
down by the Council acting by a qualified majority on a recommendation from the Commission. These arrangements shall ensure that the Community speaks with one voice on such occasions. Agreements concluded according to such arrangements shall be binding on the ECB, the Community institutions and the Member States ${ }^{78}$.

However outside the Community competence and Community Agreements regarding the Economic and Monetary Union, the Member States are free to negotiate in their own right in international bodies and conclude international agreements $\mathrm{s}^{79}$.

\section{Institutional Framework of the EMU}

The development towards the EMU has necessitated an adjustment of the functions of the existing Community institutions and the creation of new ones. At the head of the EMU power structure is the European Council which will be involved in the major EMU decisions. In its deliberations it will be assisted by the Ministers of Finance and Economy.

(a) The Commission, as always responsible for initiating Community action, is charged with additional duties of proposing policies to the Council of Ministers, assisting the Council in the surveillance of economic activities and monitoring implementation of the EMU measures. It participates in the Monetary Committee in an advisory capacity and the President of the Commission participates, without voting, in the governing body of the ECB.

(b) The European Parliament has to be informed and consulted on economic policy surveillance and certain aspects of monetary policy. Its assent is required for institutional adjustments.

(c) The Council of Ministers as the chief executive body plays a central role in the EMU. It reports to the European Council on major issues and informs the European Parliament as required. It takes decisions either by a unanimous or qualified majority vote and together with the Commission enforces the obligations arising under the system. The President of the Council, like the President of the Commission, has a non voting participation in the governing body of the $E C B^{80}$.

(d) The European System of Central Banks ${ }^{81}$ (ESCB) shall be composed of the European Central Bank (ECB) and of the central banks of the Member States. It is similar.to the German central banking system where the state banks form part of the Bundesbank. It shall be governed by the decision-making bodies of the ECB which 
are the Governing Council and the Executive Board ${ }^{82}$. The Protocol attached to the Treaty lays down the statute of the ESCB and the ECB and defines their respective functions.

The ECB shall have legal personality ${ }^{83}$ and shall enjoy in each of the Member States the most extensive legal capacity accorded to legal persons under their laws. In particular it may acquire and dispose of movable and immovable property and may be a party to legal proceedings. It is an independent ${ }^{84}$ institution and as such it shall not seek or take instructions from Community institutions, from any government of a Member State or any other body. Correspondingly, the above-mentioned entities must not seek to influence the members of the decision-making bodies of the ECB. The same principle of independence applies to the national central banks which must neither seek instructions nor be subjected to influence from Community institutions or the governments or any other bodies.

The Governing Council ${ }^{85}$ of the ECB comprising the members of the Executive Board and the governors of the national central banks shall take decisions by a simple majority, in the event of a tie the President having a casting vote. Each member shall have one vote unless otherwise provided in the Statute. A quorum of two-thirds is required. in principle only those present may vote but, exceptionally, votes may be cast by means of teleconferencing.

In certain matters (the capital of the ECB, transfer of foreign reserve assets to the $\mathrm{ECB}$, allocation of monetary income of national central banks, and allocation of net profits and losses of the ECB) decisions will be taken by a qualified majority according to the national central banks' shares in the subscribed capital of the ECB.

The Governing Council shall formulate the monetary policy of the Community including decisions relating to intermediate monetary objectives, key interest rates and the supply of reserves in the ESCB and shall establish the necessary guidelines for their implementation.

The Governing Council shall meet at least ten times a year. The President of the Council of Ministers and a member of the Commission may participate in these meetings without the right to vote. Whilst the Council may submit a motion for the deliberations of the Governing Council the President of the ECB shall be invited to participate in Council meetings when discussing matters relating to the ESCB.

The ECB shall make an annual report on the activities of the ESCB and on the monetary policy to the European Council, the Commission, the Council of Ministers 
and the European Parliament. This report shall be presented by the President of the $E C B$ in person to the Council of Ministers and the $E P$. The latter may hold a general debate on it. Moreover the President of the ECB and members of the Executive Board may, on the request of the $E P$, or on their own initiative, be heard by the competent committees of the $E P$.

The Executive Board, ${ }^{87}$ responsible for the day-to-day conduct of the business of the ECB, shall consist of the President, the Vice-President and four other members. Unlike the members of the Governing Council, all shall be full-time employees of the ECB appointed by the European Council for a non-renewable eight years term of office. They have to be nationals of the Member States and persons of recognized standing and professional experience in monetary and banking matters. The terms and conditions of their employment shall be subject to a contract fixed by the Governing Council on a proposal of a Committee comprising three members appointed by the Governing Council and three members appointed by the Council of Ministers. A member of the Board who fails to carry out his duty or is guilty of serious misconduct shall be retired by the decision of the Court of Justice on application by the Governing Council or the Executive Board.

The Executive Board ${ }^{88}$ shall implement monetary policy in accordance with the guidelines and decisions laid down by the Governing Council and carry out duties delegated to it. It shall give the necessary instructions to the national central banks.

The meetings of the Governing Council and of the Executive Board shall be chaired by the President or one of the Vice-Presidents ${ }^{89}$. The President or his nominee shall represent the ECB externally, but the ECB shall decide how the ESCB shall be represented in the field of international co-operation.

In order to align its system with the ESCB each Member State must ensure that its legislation ${ }^{90}$ concerning the national central bank is compatible with the Treaty and the Protocol. In particular the term of office of the governor of the national bank must be no less than five years and the governor may be relieved from office only on the grounds of serious misconduct or failure to perform his duties. A decision to this effect may be referred to the Court of Justice by the governor concerned or the Governing Council.

Because they are an integral ${ }^{91}$ part of the ESCB the national central banks must act in accordance with the guidelines and instructions of the ECB. Compliance shall be ensured by the Governing Council. 
Nationa ${ }^{p 2}$ central banks may perform functions other than those specified in the Protocol unless the Governing Council decides by a majority of two-thirds of votes cast that they interfere with the objectives and tasks of the ESCB. Such functions cannot be attributed to the ESCB and any responsibility or liability in this respect shall fall upon the national central banks.

Monetary ${ }^{93}$ functions and operations of the ESCB are regulated by the Protocol. These include provisions on the accounts with the ECB and the national central banks; open market and credit operations; minimum reserves; instruments on monetary control; operations with public entities; clearing and payment systems and external operations. In the latter context the ECB and the national central banks may establish relations with central banks and financial institutions in other countries and with international organizations; acquire and sell spot and forward all types of foreign exchange assets and precious metals; hold and manage foreign exchange assets which include securities and all other assets in currency of any country or units of account; and conduct all types of banking transactions in relations with third countries and international organizations, including borrowing and lending operations.

The ECB may offer advice ${ }^{94}$ and be consulted by the Council of Ministers, the Commission and the Member States on the scope and implementation of Community legislation relating to the prudential supervision of credit institutions and to the stability of the financial system.

The financial year ${ }^{95}$ of the ECB and the national central banks begins on 1 January and ends on 31 December. The annual accounts of the ECB drawn up by the Executive Board shall be published after being approved by the Governing Council. These as well as the accounts of the national central banks must be audited by independent external auditors recommended by the Governing Council and approved by the Council of Ministers.

The ECB shall have an operational capital ${ }^{96}$ of at least ECU 5,000 million provided by the national central banks who shall be its sole subscribers and holders. These subscriptions shall be made in a key which determines the weighting of the voting power according to the size of the population and the share in the Gross Domestic Product. Thus each national central bank shall be assigned a weighting equal to the sum of: $50 \%$ of the share of its country in the population of the Community, and $50 \%$ of the share of its country in the Gross Domestic Product at market prices of the Community. 
These weightings shall be adjusted ${ }^{97}$ every five years after the establishment of the ESCB.

The ECB shall be provided by the national central banks with foreign reserve assets $^{98}$ other than Member States' currencies, ECU's, IMF reserve positions and SDR's up to an amount equivalent to ECU 50,000 million. The proportions to be called up shall be determined by the Governing Council and the contributions of each national central bank shall be fixed in proportion to its share in the subscribed capital of the ECB.

Whilst the national central banks are allowed to perform transactions ${ }^{99}$ in accordance with their obligations towards international organizations all other operations in foreign reserve assets shall be subject to approval by the ECB in order to ensure consistency with the exchange rate and monetary policy of the Community.

The income ${ }^{100}$ accruing to the national central banks in the execution of the ESCB's monetary policy shall be equal to their annual income derived from their assets held against notes in circulation and deposit liabilities vis-a-vis credit institutions. An amount of the ECB's net profit not exceeding $20 \%$ shall be transferred to the general reserve fund and the remainder distributed to the shareholders of the ECB in proportion to their subscribed shares. Should the ECB incur a loss the shortfall may be offset against its general reserve fund or, if necessary, following a decision of the Governing Council, against the monetary income of the relevant financial year in proportion to the amounts received from the allocation of the monetary income.

In order to carry out its duties the ECB shall have the power to issue recommendations and opinions, take decisions and adopt regulations within the scope of its functions ${ }^{101}$. Whilst the recommendations and opinions shall have no binding force decisions shall be binding in their entirety upon those to whom they are addressed and regulations shall have general application being binding in their entirety and directly applicable in all the Member States. Moreover, under the conditions laid down by the Council of Ministers acting by a qualified majority on a proposal from the Commission and after consulting the ECB, or, acting on a recommendation from the $E C B$ and after consulting the Commission and the E P, the ECB shall be able to impose fines ${ }^{102}$ and periodic penalties on undertakings for failure to comply with the ECB regulations and decisions.

(e) The Treaty sets up a Monetary Committee ${ }^{103}$ consisting of two members

97 Protocol No. 3, art. 29.3
98 Protocol No. 3, art. 30
99 Protocol No. 3, art. 31
100 Protocol No. 3, art. 32
101 Protocol No. 3, art. 34.1 - art. 34.2
102 Protocol No. 3, art. 34.3
103 Treaty art. 109 c (1)


from each Member State and the Commission. Its function shall be advisory to the Commission and the Council of Ministers. It shall keep under review the monetary and financial situation of the Member States and the Community and report to the Commission and the Council. It shall deliver opinions on request and help to prepare Council's decisions in the field.

(f) When the Union has reached the third stage the Monetary Committee shall be replaced by the Economic and Financial Committee ${ }^{104}$. At that stage, in addition to representatives of the Member States and the Commission, the ECB will be represented. The Council of Ministers, on the proposal from the Commission, after consulting the ECB and the Committee itself shall lay down detailed provisions for its composition and functioning. In principle it will continue the work of its predecessor on a wider scale, including the review of the monetary and financial situation and the general payments system of the Member States which have obtained derogations from the EMU system. It shall report to the Commission and the Council and assist the latter in the preparation of measures to implement the system.

(g) At the beginning of the second stage the European Monetary Institute ${ }^{105}$ (EMI) will be established. It shall have legal personality and be directed and managed by a Council consisting of a President, a Vice-President and the Governors of the Central Banks of the Member States. The President, who must be a Community national, shall be appointed unanimously by the European Council on a recommendation from the Committee of Governors and, later, by the Council of the EMI after consulting the Council of Ministers and the $E P$.

The main task of the EMI, as laid down in the Protocol ${ }^{106}$ attached to the Treaty, is to develop the EMU through the second stage in particular by strengthening the co-ordination of monetary policies, preparing for the institution of a single currency, monitoring EMS and facilitating the use of ECU. It shall also act in an advisory capacity, formulating opinions and recommendations on monetary policy and exchange rate policy, to the Member States and the Council of Ministers. Being concerned with the functioning of the EMS it may also make recommendations to the national monetary authorities.

Its operational ${ }^{107}$ and technical functions include the multilateralisation of positions resulting from interventions by the national central banks in Community currencies and the multilateralization of intra-Community settlements; the administration of the short-term financing mechanism agreed in 1979 between the central banks and of the short-term monetary support mechanism agreed in 1970; and the co- 
operation in the provision of financial assistance for Member States' balance of payments.

The EMI may receive monetary reserves ${ }^{108}$ from the national central banks and issue ECU's against such assets in order to implement the EMS agreements. It may grant to third countries and international monetary institutions the status of "Other Holders" of ECU's and fix the terms under which such ECU's may be acquired, held and used by Other Holders. It may also, on the basis of bilateral contracts, hold and manage foreign exchange reserves as an agent for national central banks.

Like the ECB the EMI enjoys independence and an exalted status in the Member States. Its President ${ }^{100}$ is appointed for a period of three years from among persons of recognized expertise in monetary and banking matters. Like the President of the ECB he can be removed from office in the same circumstances. He chairs the meetings of the EMI Council, represents the EMI and is responsible for the day-today management of the EMI.

The Council of the EMI shall conduct its business according to its own rules of procedure $^{110}$. Like the ECB it is empowered to issue non-binding opinions and recommendations as well as binding decisions ${ }^{114}$. It shall also adopt guidelines addressed to the national central banks for the implementation of the third stage. Such guidelines are not binding but shall be submitted for decision to the ECB.

The EMI shall have its own resources ${ }^{112}$ to cover the cost of the performance of its tasks. These shall be contributed by the national central banks in accordance with the key established for the financing of the ESCB.

The EMI shall be wound up on the establishment of the ECB during the third stage.

(h) The Court of Justice ${ }^{113}$ has to ensure the conformity of the EMU with the Treaty. Whilst it is not concerned with the technicalities of the EMU it has to exercise judicial control over its implementation. Thus it may be called upon to adjudicate upon the exercise of the powers granted to the Community institutions, the conduct of the Member States in the performance of their duties and the constitutional issues arising from the creation of the new institutions. It may also have to adjudicate upon the exercise of the Community external relations corollary to the EMU. 
More specifically the Court of Justice ${ }^{114}$ shall have jurisdiction in any dispute between the ECB and its servants and the EMI and its servants in matters concerning their employment.

The acts or omissions of the ECB and of the EMI shall be subject to review or interpretation by the Court of Justice like the acts or omissions of Community institutions. Conversely the ECB and the EMI shall be able, within their fields of competence, to institute proceedings in accordance with articles 173 to 178 and 184 of the EEC Treaty. The ECJ shall also have jurisdiction to hear cases pursuant to any arbitration clause contained in a contract concluded by or on behalf of the ECB or the $\mathrm{EMI}$ irrespective of whether the contract in question is governed by public or private law. Since both the ECB and the EMI are subject to non-contractual liability in accordance with article 215 (2) of the EEC Treaty cases in that category too would be heard by the ECJ.

The duties of the national central banks ${ }^{115}$ under the EMU shall be enforceable by the ECB in a manner analogous to the enforcement action of the Commission under article 169 of the EEC Treaty. Accordingly, if the ECB considers that a national central bank has failed to fulfill an obligation under the statute of the ESCB it shall deliver a reasoned opinion giving time to reply and to comply and in the event of noncompliance, may bring the matter before the ECJ.

Lastly, decisions regarding compulsory retirement ${ }^{146}$ of the President and of the members of the Executive Board of the ECB and of the President of the EMI shall be within the jurisdiction of the ECJ.

However disputes ${ }^{117}$ between the ECB or the EMI on the one side and its creditors, debtors or any other person, on the other, fall within the jurisdiction of the competent national courts unless jurisdiction in such cases has been specifically conferred upon the ECJ. The national central banks shall be liable according to their respective national laws.

\section{Implementation of the EMU}

A time-table for the implementation of the EMU in three stages was laid down at Maastricht. It is at present in the first stage under the existing Treaty provisions leading to the completion of the internal market, a further co-ordination of Member States' economic and fiscal policies and the single financial area with all the Member States in the European Monetary System. 
The second stage begins when the new Treaty comes into force and, more specifically, on 1 January $1994^{118}$ with the establishment of the EMI.

The Commission and the EMI will report on the progress achieved by the Member States towards the convergence of their economic and monetary policies. By 31 December $1996^{119}$ the U K ought to notify the European Council whether it intends to move with the others to stage three. If the majority of the Member States (i.e. seven or six without the $U \mathrm{~K}$ ) have met four convergence criteria, i.e. price stability (a rate of inflation no more than $1.5 \%$ above the average of the three best performing countries); government deficit not exceeding $3 \%$ of the GDP and public debt not exceeding $60 \%$ of the GDP; stable exchange rates within the EMS; and interest rates no more than $2 \%$ above three best-performing countries over the previous 12 months; the Council will, by a qualified majority decision, move to stage three on 31 December 1996. If no date has been fixed by the end of 1997 the ESCB must be established by 1 July 1998 and stage three will "irrevocably" begin on 1 January $1999^{120}$. The Council will determine, by a qualified majority, which Member States are able to participate. Those which are not will be subject to derogation. At that point the participating States will agree the conversion rates at which their currencies will be "irrevocably" fixed and will be exchanged for ECUs. The ECU will then become the single currency.

\section{The British Protocol}

Under a special Protocol ${ }^{121}$ the UK has negotiated the right to opt out of stage three of the EMU without a positive decision of the government and parliament. However the U K must notify the European Council by 31 December 1996 whether it intends to move to stage three or by 1 January 1998 if no decision has yet been taken by the Council.

If the U K does not join stage three it shall retain control of the monetary and exchange rate policy and, therefore, will not be subject to EC discipline. However, having accepted stage two, it is bound not to run into excessive public deficit and the Bank of England shall pay up its subscribed capital transfer to ECB foreign reserve assets and contribute to its reserves on the same basis as the national central bank of a Member State whose derogation has been abrogated ${ }^{122}$.

During its absence the weighted vote of the $U \mathrm{~K}$ shall be inapplicable when computing the qualified majority for the EMU decisions. Moreover the $\mathrm{U} K$ shall not 
participate in the appointment of the Executive Board of the ECB; the ECB statutes will not apply to the UK and references to the Community or the Member States will not include the UK References to national central banks will not include the Bank of England.

However the $\mathrm{UK}$ is free to change its mind and move to stage three it it satisfies the four criteria of convergence.

\section{Conclusions}

The Maastricht Treaty is certainly a landmark in European integration as it moves the Community further towards a federal system. Although the vision of the United Europe has been dimmed by the abstruse text of the Treaty bearing the hallmark of close negotiations there is progress both in the political and economic field. The balance of power is still in favour of the Member States though another intricate procedure has been added to upgrade a little the $E P$. The convergence of economic and monetary policies advances the idea of central control at the expense of national sovereignty and, in a sense, confirms the theory that economic integration will further political integration. It remains to be seen, though, whether the timetable of Maastricht will be maintained.

The British abstention from stage three of the EMU reflects not only a cautious (if not obstructive) stance but also reluctance to divest the country of what has been left of national sovereignty in favour of Community centralism. Yet centralism is inevitable in the building of a United Europe. It also reflects the fact that Europe is still on the agenda of domestic politics bedevilled by partisanship and lack of national unity in this most imaginative international venture of this century. 